\title{
Specific Identification of Fraction I-positive Pasteurella pestis Colonies on Antiserum-Agar Plates
}

\author{
JOHNNIE M. ALBIZO AND MICHAEL J. SURGALLA \\ Biological Sciences Laboratory, Fort Detrick, Frederick, Maryland 21701
}

Received for publication 6 February 1968

\begin{abstract}
A method is described for the use of antiplague serum in Blood Agar Base plating media to detect fraction I-positive Pasteurella pestis. The antiserum was produced conveniently and in large volume in rabbits by use of Cutter plague vaccine combined with Freund's complete adjuvant. $P$. pestis colonies were specifically identified within $48 \mathrm{hr}$ after plating by the presence of a precipitin ring surrounding each colony. The basis of the test was shown to be a precipitin reaction between fraction I antigen released from $\boldsymbol{P}$. pestis colonies after chloroform vapor treatment and fraction I antibody present in the antiserum-agar medium.
\end{abstract}

Serological techniques currently used for detecting or identifying Pasteurella pestis are based upon the specific reaction between fraction $I$ antigen produced by plague organisms at $37 \mathrm{C}$ and specific antibody produced against fraction I antigen $(2,5-8,10,17)$. These methods detect fraction I antigen present in cultures, culture extracts, or tissues and require either specific fraction I antibody or purified fraction I antigen and, in some cases, prior isolation of the suspected organism.

This paper describes an additional serological test for $\boldsymbol{P}$. pestis that utilizes the specific fraction I antigen-antibody reaction. By this method, $P$. pestis colonies originating largely from single cells can be identified on antiserum-agar plates. A large supply of specific antiserum, required for extensive use of the method, was conveniently obtained with commercially available vaccine and adjuvant. The nature of the test makes feasible the identification of $P$. pestis colonies in the presence of contaminating organisms.

\section{Materials AND MethodS}

Production of antisera. Each of four New Zealand White rabbits $(2.5$ to $3 \mathrm{~kg}$ ) was injected initially with $2 \mathrm{ml}$ of an equal mixture of plague vaccine (Cutter Laboratories, Berkeley, Calif.) and Freund's complete adjuvant (Difco). This dose (containing $2 \times$ $10^{9}$ organisms) was divided, and $0.75 \mathrm{ml}$ was injected into the large muscle of each hind leg and $0.5 \mathrm{ml}$ was injected subcutaneously in the dorsal neck region. One week later, each rabbit was injected with $1 \mathrm{ml}$ of undiluted Cutter plague vaccine $\left(2 \times 10^{9}\right.$ organisms without adjuvant), $0.5 \mathrm{ml}$ intramuscularly into one hind leg and $0.5 \mathrm{ml}$ subcutaneously in the dorsal neck region. Four uninoculated rabbits served as a source of normal rabbit serum throughout the experiment. Rabbits were bled from the marginal ear vein before receiving the first injection, after the 6th week, and weekly thereafter through the 16 th week. Xylene was applied locally to the rabbit's ear to facilitate collection of $40 \mathrm{ml}$ of blood from each rabbit per bleeding. Antisera were sterilized by filtering through $0.45-\mu$ disposable nalgene filter units (Nalge Co., Inc., Rochester, N.Y.) under only slight vacuum.

Schedule for testing antisera. Sera obtained from normal and immunized rabbits each week were tested individually for fraction I antibody titer by use of the gel diffusion technique of Ouchterlony (12) and the bacterial agglutination test, with Cutter plague vaccine as a source of fraction I antigen. Individual antisera were combined in equal volumes to form weekly pools of antisera that were, in turn, tested for fraction I antibody titer. Weekly antiserum pools and a large antiserum pool containing equal volumes of the antisera collected from the 9th through the 16th week were tested for precipitin ring titer and specificity of reaction in antiserum-agar plates.

Gel precipitin test. Standard disposable petri plates $(100 \times 15 \mathrm{~mm})$ containing a mixture of $1 \%$ Ionagar no. 2 (Consolidated Laboratories, Inc., Chicago Heights, Ill.), $0.01 \%$ Merthiolate, and $0.9 \% \mathrm{NaCl}$ were used to determine gel precipitin titers. Seven wells, $0.5 \mathrm{~mm}$ in diameter and $2 \mathrm{~mm}$ apart, were punched into the solidified diffusion agar by use of a hollow cylindrical steel borer and a plastic template. Cutter plague vaccine (undiluted) was deposited in the central well. After standard fraction I antiserum (9) was deposited in one of the outer wells, twofold dilutions of antisera in $0.85 \% \mathrm{NaCl}$ were deposited in four of the five remaining wells. One well, located between the fraction I antibody standard and the 
last dilution of the test serum, was left vacant to avoid false end points. Parallel tests were conducted with normal rabbit sera collected at the same time and processed identically to the antiplague sera. The last dilution of antiserum producing a distinct precipitin band continuous with the precipitin band formed between the fraction I antigen source and the fraction I antibody standard was considered to be the end point of the titration (after 18 to $24 \mathrm{hr}$ at $26 \mathrm{C}$ ).

Bacterial agglutination test. A $0.1-\mathrm{ml}$ amount of Cutter plague vaccine (freshly diluted 1:10 in $0.85 \%$ $\mathrm{NaCl}$ ) was mixed in the small depressions of a disposable agglutination tray with an equal volume of antiserum diluted in $0.85 \% \mathrm{NaCl}$. Parallel tests were conducted with normal rabbit sera collected at the same time and processed identically to the antiplague sera. After mixing the components by a gentle circular motion of the tray, a sheet of plastic wrap was placed over the entire tray, and the tray was incubated at $26 \mathrm{C}$. After incubation for 18 to $24 \mathrm{hr}$, agglutination trays were viewed through a dissecting microscope with oblique transmitted light. The last dilution of antiserum producing pronounced, large flaky aggregates was considered to be the end point of the titration.

Preparation of antiserum-agar plates. Filtered antiserum was diluted with sterile $0.85 \% \mathrm{NaCl}$, brought to $37 \mathrm{C}$ in a water bath, and added to an equal volume of sterile $8 \%$ Blood Agar Base (Difco; pH 6.8) that had been allowed to cool for at least 1 $\mathrm{hr}$ in a water bath maintained at $55 \mathrm{C}$. The antiserumagar mixture was swirled gently in a flask to mix the components completely without the excessive formation of air bubbles. Rapidly, 8- to 10-ml quantities of antiserum-agar were poured into sterile, standardsize disposable petri plates. Uniform plates were prepared by covering one half of the bottom surface of each petri plate with antiserum-agar and immedi- ately tilting the plate to distribute the material over the entire bottom surface of each plate. Plates were sealed in plastic bags immediately after the agar solidified and were stored at $4 \mathrm{C}$ until used.

Bacterial test strains. Bacterial strains were standard laboratory stocks with the exception of clinical isolates; Streptococcus pyogenes (group A) and $S$. viridans were obtained through the courtesy of Martha K. Ward, and Staphylococcus aureus (80-81 phage type) was obtained through the courtesy of Robert A. Altenbern.

Precipitin ring test in antiserum-agar plates. Bacterial test strains grown on Difco Blood Agar Base slants for 18 to $24 \mathrm{hr}$ at $26 \mathrm{C}$ were diluted 7 logs with sterile $2.5 \%$ Heart Infusion Broth (Difco). Of this dilution, $0.1 \mathrm{ml}$ (containing 50 to 100 organisms) was spread on the surface of antiserum-agar plates with glass spreading rods. Pneumococci and streptococci were grown on Blood Agar slants for $48 \mathrm{hr}$ at $26 \mathrm{C}$ and were diluted 6 logs for application to antiserum-agar plates. Plates were incubated at $37 \mathrm{C}$ for $40 \mathrm{hr}$ or until $P$. pestis colonies were 0.5 to $1 \mathrm{~mm}$ in diameter. Plates were then exposed to chloroform vapor for $10 \mathrm{~min}$ by inverting them over inverted glass petri dish covers containing $2 \mathrm{ml}$ of chloroform on a gauze sponge $(2 \times 2$ inches or $5 \times 5 \mathrm{~cm}, 12$ ply). The plates were then removed and left inverted (agar surface down) in a tilted position for $10 \mathrm{~min}$ to eliminate chloroform vapor. Chloroform-treated plates were incubated at $37 \mathrm{C}$ and were examined after 2, 4, 6, and $24 \mathrm{hr}$ for precipitin ring formation. Observations were made with a dissecting microscope and oblique transmitted light.

Comparison of precipitin rings with a standard fraction I antigen-antibody system. $P$. pestis strain Alexander was plated on antiserum-agar plates containing pooled ( 9 to 16 weeks) antiplague serum diluted 1:128. The plates were incubated for $48 \mathrm{hr}$

TABLE 1. Weekly gel precipitin and agglutinin titers of individual and pooled rabbit antiplague sera tested against Cutter plague vaccine ${ }^{a}$

\begin{tabular}{|c|c|c|c|c|c|c|c|c|c|c|}
\hline \multirow{3}{*}{$\begin{array}{l}\text { Weeks post- } \\
\text { immunization }\end{array}$} & \multicolumn{10}{|c|}{ Reciprocal of antibody titer } \\
\hline & \multicolumn{2}{|c|}{ Rabbit 1} & \multicolumn{2}{|c|}{ Rabbit 2} & \multicolumn{2}{|c|}{ Rabbit 3} & \multicolumn{2}{|c|}{ Rabbit 4} & \multicolumn{2}{|c|}{ Rabbits $1-4$ pooled } \\
\hline & $\mathbf{P}$ & A & $\mathbf{P}$ & A & $\mathbf{P}$ & A & $\mathbf{P}$ & A & $\mathbf{P}$ & A \\
\hline $\mathbf{0}$ & 0 & $\mathbf{0}$ & 0 & 0 & 0 & $\mathbf{0}$ & 0 & 0 & 0 & 0 \\
\hline 6 & 128 & 16 & 64 & 16 & 32 & 8 & 16 & 8 & 32 & 8 \\
\hline 7 & 128 & 16 & 128 & 32 & 32 & 8 & 32 & 8 & 32 & 8 \\
\hline 8 & 128 & 32 & 128 & 32 & 32 & 8 & 32 & 8 & 64 & 16 \\
\hline 9 & 128 & 32 & 128 & 32 & 64 & 8 & 64 & 16 & 128 & 32 \\
\hline 10 & 256 & 64 & 64 & 32 & 128 & 16 & 64 & 64 & 128 & 64 \\
\hline 11 & 256 & 32 & 128 & 32 & 128 & 16 & 128 & 16 & 128 & 32 \\
\hline 12 & 256 & 32 & 128 & 32 & 256 & 16 & 128 & 16 & 256 & 32 \\
\hline 13 & 256 & 64 & 256 & 32 & 256 & 16 & 128 & 16 & 256 & 32 \\
\hline 14 & 256 & 64 & 256 & 64 & 128 & 32 & 128 & 16 & 256 & 32 \\
\hline 15 & 256 & 32 & 256 & 32 & 128 & 32 & 128 & 16 & 256 & 32 \\
\hline & 256 & 32 & 128 & 32 & 128 & 16 & 64 & 16 & 256 & 16 \\
\hline 9-16 (pool) & & & & & & & & & 256 & 32 \\
\hline
\end{tabular}

${ }^{a} \mathbf{P}=$ precipitin titer $\mathbf{A}=$ agglutinin titer . 
and subsequently were exposed to chloroform vapor for $10 \mathrm{~min}$. Immediately, two wells were punched in the nutrient agar adjacent to each of several P. pestis colonies with a special 13-gauge needle. Standard fraction I antigen and fraction I antibody provided by William D. Lawton (9) were added to the wells located adjacent to $\boldsymbol{P}$. pestis colonies. The plates were incubated at $37 \mathrm{C}$ and were examined within 24 hr.

Replication of colonies. Fraction I-positive $P$. pestis colonies grown on antiserum-agar plates for $48 \mathrm{hr}$ at $37 \mathrm{C}$ were replicated, by use of velveteen, to a second antiserum-agar plate containing pooled antiplague serum diluted 1:128. The original plate was then treated with chloroform vapor for $10 \mathrm{~min}$. The replicate plate was incubated at $37 \mathrm{C}$ for $48 \mathrm{hr}$ before being subjected to chloroform vapor treatment for $10 \mathrm{~min}$.

Variation of chloroform vapor treatment. P. pestis colonies $(40 \mathrm{hr} ; 0.5$ to $1 \mathrm{~mm}$ in diameter) grown at $37 \mathrm{C}$ on antiserum-agar plates were exposed to chloroform vapor for 15 and $30 \mathrm{sec}$ and $1,1.5,2,2.5$, and 5 min. Plates were incubated at $37 \mathrm{C}$ for $24 \mathrm{hr}$ and were observed to determine the shortest exposure to chloroform vapor that would result in precipitin ring formation around all colonies present on each plate. Several colonies from each plate were picked and were streaked onto plates containing Blood Agar Base (Difco). Plates were incubated at $26 \mathrm{C}$ for $48 \mathrm{hr}$ and were observed to determine the longest exposure to chloroform vapor that would permit viability of all colonies picked from each plate.

\section{RESULTS}

Gel precipitin and bacterial agglutinin titers of individual and pooled antisera were elevated by the 9th week and remained reasonably high through the 16th week (Table 1). The large pool

TABLE 2. Weekly precipitin ring titers of pooled rabbit antiplague sera against Pasteurella pestis colonies (Alexander) in antiserum-agar plates

\begin{tabular}{l|l|l|l|l|l|l}
\hline \multirow{2}{*}{$\begin{array}{c}\text { Weeks post- } \\
\text { immunization }\end{array}$} & \multicolumn{5}{|c}{ Formation of precipitin rings } \\
\cline { 2 - 6 } & $16^{b}$ & 32 & 64 & 128 & 256 & 512 \\
\hline 0 & - & - & - & - & & \\
6 & + & + & + & - & & \\
7 & + & + & + & + & - & \\
8 & + & + & + & + & - & \\
9 & & + & + & + & - & \\
10 & & + & + & + & - & \\
11 & & + & + & + & - & \\
12 & & + & + & + & - & \\
13 & & + & + & + & + & + \\
14 & & + & + & + & + & + \\
15 & & + & + & + & + & + \\
16 & & + & + & + & + & + \\
$9-16$ (pool) & & + & + & + & + & + \\
\hline
\end{tabular}

a Plus, positive; minus, negative.

$b$ Reciprocal of final serum dilution.
TABLE 3. Weekly tests of specificity of pooled rabbit antiplague sera for fraction I-positive colonies in antiserum-agar plates

\begin{tabular}{|c|c|c|c|c|}
\hline \multirow{2}{*}{$\begin{array}{l}\text { Weeks post- } \\
\text { immunization }\end{array}$} & \multicolumn{4}{|c|}{ Precipitin ring formation $^{a}$} \\
\hline & $\left|\begin{array}{c}\text { Pasteurella } \\
\text { pestis } \\
\text { Alexander }\end{array}\right|$ & $\begin{array}{l}P . \text { pestis } \\
\text { M23 }\end{array}$ & $\mid \begin{array}{l}\text { P. psendo- } \\
\text { iubercu- } \\
\text { losis } \mathrm{PB1}^{+}\end{array}$ & 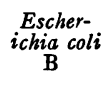 \\
\hline 0 & - & - & - & - \\
\hline 6 & + & - & - & - \\
\hline 7 & + & - & - & - \\
\hline 8 & + & - & - & - \\
\hline 9 & + & - & - & - \\
\hline 10 & + & - & - & - \\
\hline 11 & + & - & - & - \\
\hline 12 & + & - & - & - \\
\hline 13 & + & - & - & - \\
\hline 14 & + & - & - & - \\
\hline 15 & + & - & - & - \\
\hline 16 & + & - & - & - \\
\hline 9-16 (pool) & + & - & - & - \\
\hline
\end{tabular}

a Plus, positive; minus, negative. Final serum dilution was $1: 32$.

of antiserum collected from the 9th through the 16th week exhibited a comparable antibody titer. Normal rabbit sera used in a parallel study failed to exhibit antibody titers against the test antigen.

Weekly antiserum pools collected during this study were tested for precipitin ring titer (Table 2) and specificity (Table 3) in antiserum-agar plates. Precipitin ring titers (Table 2) were elevated by the 7 th week, reached a peak at the 13th week, and remained elevated through the 16th week. The large antiserum pool (9 to 16 weeks) showed a precipitin ring titer equal to the highest weekly titers obtained during the experiment. Normal rabbit sera failed to react with the test antigen in a parallel study.

All weekly antiserum pools and the large pool of antiserum collected from the 9th through the 16th week were specific for fraction I-positive $P$. pestis colonies (strain Alexander) when tested at the 1:32 dilution (Table 3). Corresponding normal rabbit serum pools did not form precipitin rings with $P$. pestis colonies (strain Alexander).

As indicated in Table 2, the large antiserum pool ( 9 to 16 weeks) showed a precipitin ring titer of $1: 512$ in antiserum-agar plates. $P$. pestis colonies from this titration are shown in Fig. 1. The precipitin ring appearing at the $1: 16$ dilution of the antiserum (A) reprreents antibody other than fraction I antibody. This antibody is effectively diluted out at the $1: 32$ dilution, whereas fraction I antibody becomes sufficiently dilute to permit a precipitin ring to form close to the $P$. pestis colony (B). Optimal precipitin rings were observed at the 1:128 dilution (D); therefore, this 
dilution of the large antiserum pool was selected as the standard dilution for use in antiserum-agar plates.

Several well-characterized strains of $\boldsymbol{P}$. pestis (including some fraction I-negative strains), $P$. pseudotuberculosis, and strains from other genera were tested in antiserum-agar plates containing pooled antiserum diluted $1: 128$ (Table 4). Only those strains of $P$. pestis known to produce fraction I promoted precipitin ring formation. Colonies from four of the several bacterial strains used in the specificity test are shown in Fig. 2. Of the two $P$. pestis strains shown in Fig. 2, only Alexander (A) produced fraction I antigen.

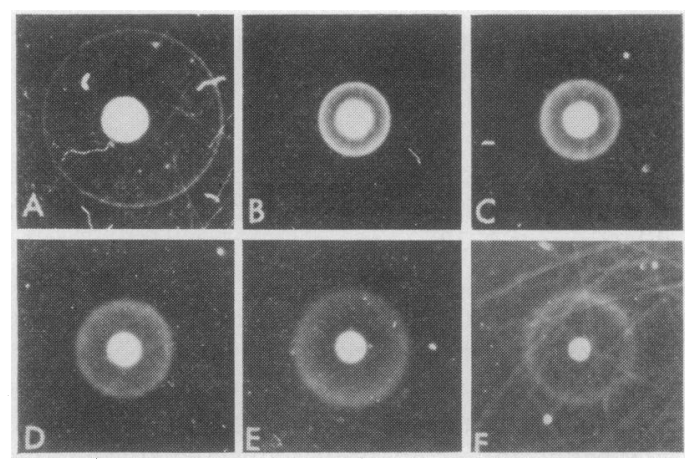

Fig. 1. Precipitin rings surrounding Pasteurella pestis colonies grown on nutrient agar containing antiplague serum (9-16 week pool) diluted: $(A)$ 1:16, (B) 1:32, (C) 1:64, (D) 1:128, (E) 1:256, and $(F)$ 1:512.
$P$. pestis Alexander (a fraction I-positive strain) did not form precipitin rings when colonies were allowed to develop at $26 \mathrm{C}$. Likewise, $P$. pestis Alexander colonies did not form precipitin rings if allowed to grow for 4 days at $37 \mathrm{C}$ in the absence of chloroform-vapor treatment. Negative results were also obtained when $\boldsymbol{P}$. pestis colonies (Alexander) were grown at $37 \mathrm{C}$ on nutrient agar containing normal rabbit serum diluted 1:128 (Fig. 3).

The chloroform-vapor treatment $(10 \mathrm{~min})$ initially used to hasten the formation of precipitin rings killed the organisms. To facilitate further study of $\boldsymbol{P}$. pestis, colonies were replicated to another antiserum-agar plate prior to treating the original plate with chloroform vapor. Figure 4 shows both original and replicate plates after they were treated with chloroform vapor for $10 \mathrm{~min}$. Colony patterns were similar on both plates, demonstrating the validity of using a replication procedure in conjunction with the antiserum-agar method.

To permit further study of $P$. pestis colonies without resorting to replication procedures, antiserum-agar plates containing $\boldsymbol{P}$. pestis colonies were exposed briefly to chloroform vapor. Results indicated that $30 \mathrm{sec}$ of exposure to chloroform vapor was sufficient to produce precipitin rings in all of the fraction I-positive $P$. pestis strains shown in Table 4. The test was specific for fraction I-positive $P$. pestis, with a chloroform exposure time of $30 \mathrm{sec}$, because fraction I-negative $P$. pestis. $P$. pseudotuberculosis, and strains from other genera were unreactive. Improved

TABLE 4. Specificity of pooled (9 to 16 weeks) rabbit antiplague serum (1:128 dilution) for fraction I-positive Pasteurella pestis colonies in antiserum-agar plates

\begin{tabular}{|c|c|c|c|c|c|}
\hline Organism & $\begin{array}{c}\text { Pptn } \\
\text { ring }\end{array}$ & Organism & $\begin{array}{c}\text { Pptn } \\
\text { ring }\end{array}$ & Organism & $\begin{array}{c}\text { Pptn } \\
\text { ring }\end{array}$ \\
\hline $\begin{array}{l}\text { P. pestis }\left(\mathrm{F} 1^{+}\right)^{a} \\
\text { Alexander } \\
\text { Kim 10 } \\
\text { Salizar } \\
\text { Shasta } \\
\text { Saka } \\
\text { Yokohoma } \\
\text { MP6 } \\
\text { P477 } \\
\text { Bryans (M41) } \\
\text { A4 } \\
\text { A12 } \\
\text { A16 } \\
\text { G32 } \\
\text { EV76 }\end{array}$ & $\begin{array}{l}+ \\
+ \\
+ \\
+ \\
+ \\
+ \\
+ \\
+ \\
+ \\
+ \\
+ \\
+ \\
+ \\
+\end{array}$ & $\begin{array}{l}P \text {. pestis }\left(\mathrm{F}^{-}\right)^{b} \\
\text { M23 } \\
019 \\
\text { B14 } \\
\text { G35 } \\
\text { Jaffa (G50) } \\
\text { Java } \\
\text { TRU } \\
\text { P. pseudotuberculosis } \\
\text { PB1+(I) } \\
\text { EP2+ (II) } \\
\text { MD31 (III) } \\
\text { Neilson (IV) } \\
\text { PBS(25) (V) } \\
\text { Alaska(1B) }\end{array}$ & $\begin{array}{l}- \\
- \\
= \\
- \\
- \\
- \\
- \\
- \\
= \\
-\end{array}$ & $\begin{array}{l}\text { Streptococcus pyogenes (group A) } \\
\text { S. viridans (human throat) } \\
\text { Staphylococcus aureus }(80-81 \text { phage type) } \\
\text { Diplococcus pneumoniae (type I) } \\
\text { Klebsiella pneumoniae ATCC } 13883 \\
\text { Salmonella typhi ATCC } 167 \\
\text { Shigella sonnei ATCC } 9290 \\
\text { Escherichia coli B } \\
\text { Pasteurella X. (Winblad) } \\
\text { Yersinia enterocolytica } \\
\text { Proteus morganii ATCC } 8019 \\
\text { Enterobacter aerogenes ATCC } 13048 \\
\text { Pseudomonas aeruginosa ATCC } 10145 \\
\text { Serratia marcescens ATCC } 13880\end{array}$ & $\begin{array}{l}- \\
- \\
- \\
- \\
- \\
- \\
- \\
- \\
- \\
-\end{array}$ \\
\hline
\end{tabular}

${ }^{a}$ Fraction I positive strains.

${ }^{b}$ Fraction I negative strains.

${ }^{c}$ Serotype of $P$. pseudotuberculosis. 
precipitin rings were obtained with chloroform exposure times of 1 and $1.5 \mathrm{~min}$, without loss of specificity or viability of the colonies. Some colonies were killed after a 2-min exposure to chloroform vapor, and all of the colonies were killed after $2.5 \mathrm{~min}$.

Evidence gained during this study indicated that precipitin ring formation was based upon the specific reaction between fraction I antigen released from $P$. pestis cells after chloroform vapor treatment and fraction $I$ antibody present in nutrient agar plates. Direct evidence of this is presented in Fig. 5. The joining of the precipitin rings surrounding both antigen sources and the dissolving of the precipitin ring between antigen sources (A) and (B) are considered evidence that the two precipitin reactions are homologous.
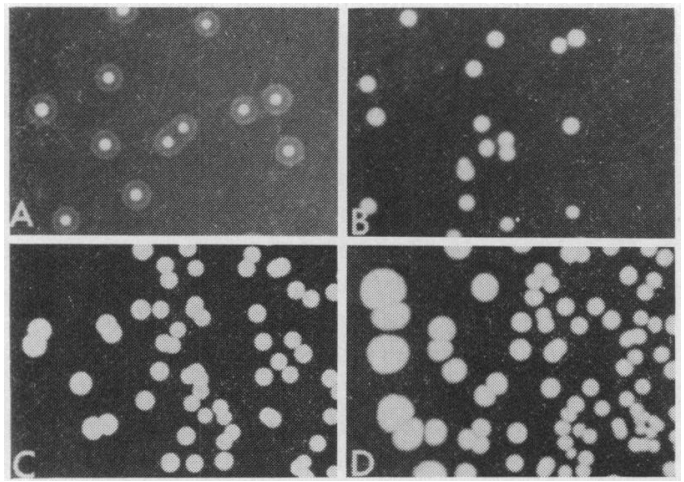

Fig. 2. Specificity of pooled rabbit antiplague serum for fraction I-positive Pasteurella pestis colonies (Alexander) in antiserum-agar plates. (A) $P$. pestis (Alexander); (B) P. pestis (M23); (C) $P$. pseudotuberculosis $\left(\mathrm{PBI}^{+}\right)$; and $(D)$ Escherichia coli $B$.
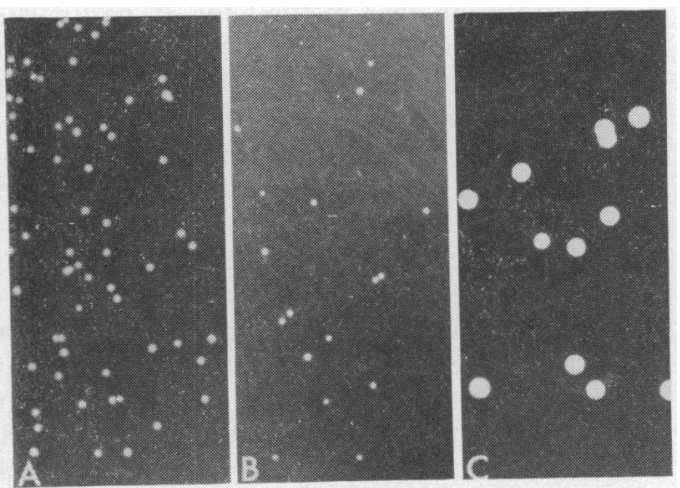

FIG. 3. Negative reactions observed with Pasteurella pestis (Alexander) in antiserum-agar and normal serum-agar plates. (A) Antiserum-agar $(26 C) ;(B)$ normal serum-agar $(37 \mathrm{C}) ;$ and $(C)$ antiserum-agar (37 C) 4 days without chloroform.
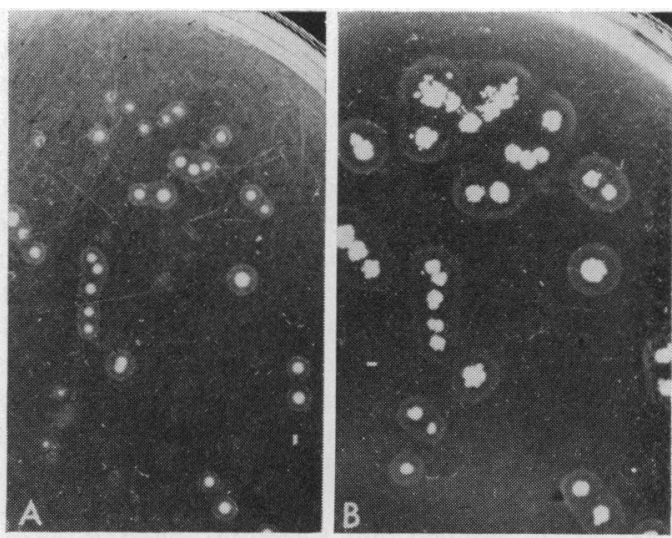

Fig. 4. Replication of Pasteurella pestis colonies (Alexander) from antiserum-agar plate. $(A)$ Original plate, and $(B)$ replicate plate.

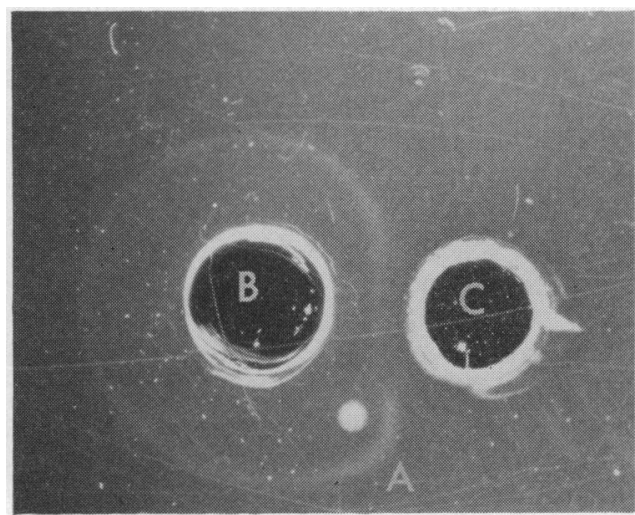

FIG. 5. Comparison of precipitin ring surrounding fraction I-positive Pasteurella pestis colony with standard fraction I antigen-antibody system. $(A) P$. pestis colony, $(B)$ fraction I antigen, and $(C)$ fraction I antibody.

\section{Discussion}

The diagnostic potential of identifying bacterial colonies growing on nutrient agar containing specific antiserum by the formation of precipitin rings surrounding the colonies was demonstrated many years ago $(11,13,15)$; however, until the present time, this concept had not been successfully applied to $P$. pestis.

Delay in developing an antiserum-agar method for $P$. pestis may be attributed to two major factors: (i) the difficulty involved in obtaining large supplies of specific fraction I antisera and (ii) the tendency for $P$. pestis to hold fraction 1 antigen tightly when grown on agar surfaces.

Both obstacles were overcome in the present study because a large volume of specific anti- 
plague serum was obtained without first resorting to the task of purifying fraction I antigen (1), and chloroform vapor was utilized to release fraction I antigen from $P$. pestis cells. The method of antiserum production reported in this study was selected on the basis of several considerations: (i) a large supply of specific antiserum would be required for extensive use of the antiserum-agar method, (ii) the method of antiserum production should be convenient and should utilize a standard antigen to minimize variables, (iii) animals injected with Cutter plague vaccine and Freund's adjuvant yielded antisera containing fraction I antibody and only rarely other detectable antibodies (9), (iv) studies by Chen, Larson, and Meyer (4) showed that Formalin-killed $P$. pestis evoked the highest antibody response when given at high antigenic mass with aluminum hydroxide adjuvant, (v) Freund's complete adjuvant is a potent adjuvant of long standing and can be obtained commercially (Difco) to minimize variables, (vi) our preliminary experiments with groups of rabbits immunized with Cutter plague vaccine and Freund's complete adjuvant by use of different schedules and dosages indicated that fraction I antibody titers remained elevated over a period of several weeks and that two massive injections spaced 1 week apart consistently gave higher titers, and (vii) combining all considerations, it was assumed that injection into rabbits of a large antigenic mass of Cutter plague vaccine with Freund's complete adjuvant would result in the production of antiserum that would contain predominantly fraction I antibody over a period of several weeks. The antiserum could then be made specific for fraction I-positive $P$. pestis simply by diluting out the unwanted antibodies.

It is not clear why fraction I antibody should predominate in rabbits injected with a massive dose of Cutter plague vaccine and Freund's complete adjuvant. Perhaps the use of Formalin to kill the cells during vaccine production or the use of phenol as a preservative, or the use of both, preferentially alters or damages antigens other than fraction I. Perhaps Formalin alters fraction I, making it a more effective antigen (in rabbits) in combination with adjuvant; Chen, Larson, and Meyer (4) concluded that this was true in guinea pigs. The antiplague serum produced for use in the present method is not pure in the absolute sense. Antibody other than fraction I antibody may be present at concentrations too dilute to permit visible reaction. Conceivably, antibody other than fraction I antibody could be present at concentrations sufficiently high to permit reaction; however, the reaction may not occur because the corresponding antigen may not be produced in colonies grown on agar surfaces. On the other hand, it may be that the corresponding antigen is produced but is obscured by fraction I antigen and is therefore not available for diffusion or release by chloroform vapor treatment. If the latter is true, one could perhaps liberate the antigen by use of solvents other than chloroform or by a combination of solvents used simultaneously or in series. Whatever the actual situation is with regard to additional antibodies in the antiserum and the presence or absence or availability of other antigens within the cells of the colonies, it may be stated that, under the conditions of the present antiserum-agar test, the antiserum is specific for fraction I-positive $\boldsymbol{P}$. pestis.

The antiserum-agar technique, based on precipitin rings surrounding colonies grown on nutrient agar containing specific antiserum, was investigated because the concept offered possibilities for pursuing areas of plague research which cannot be pursued with current methods. The method is especially suited to $P$. peitis because fully virulent $P$. pestis strains (3) and most known avirulent and attenuated strains produce fraction I antigen. Also, it is advantageous that fraction $I$ antigen is unique to $P$. pestis. Even $P$. pseudotuberculosis, the closest known antigenically related relative of $P$. pestis, does not produce fraction I antigen. The effectiveness of the antiserum-agar method is clearly demonstrated in the two following observations. The Alaskan isolate of $\boldsymbol{P}$. pseudotuberculosis that yielded a false-positive immunofluorescent reaction with fraction Ib antibody (14) failed to react in the present test system. At the other extreme, the Bryans isolate of $P$. pestis that yielded a negative reaction in fluorescent staining tests employing specific fraction I antibody (16) was readily detected with our antiserum-agar technique.

The antiserum-agar method for $P$. pestis was designed with certain expectations ultimately in mind. With the antiserum-agar method employing fraction I antibody, one should be able to determine the fraction I (genetic potential) of individual cells within a $P$. pestis population, assuming of course that the colonies are derived largely from single cells. This would be most helpful to anyone concerned with mutations or genetic exchange involving fraction $I$ antigen. Fraction I-positive $P$. pestis should also be detectable in the presence of contaminating organisms when selective media containing specific fraction I antibody are used. Simultaneous isolation and identification of $\boldsymbol{P}$. pestis could be accomplished on antiserum-agar plates, thus simplifying procedures for confirming the clinical diagnosis of plague and identifying $P$. pestis in ecological surveys. 


\section{ACKNOWLEDGMENTS}

We acknowledge the excellent technical assistance of Jerry D. Gordon. We thank Earl D. Beesley for helpful suggestions and for providing characterized laboratory stock bacterial strains. We are grateful to William D. Lawton for providing a fraction I antigen-antibody system for gel diffusion tests.

\section{LITERATURe Cited}

1. BAKer, E. E., H. Sommer, L. E. Foster, E. Meyer, AND K. F. Meyer. 1952. Studies on immunization against plague. I. The isolation and characterization of the soluble antigen of Pasteurella pestis. J. Immunol. 68:131-145.

2. Baltazard, M., D. H. S. Davis, R. Devignat, G. Girard, M. A. Gohar, L. Kartman, K. F. Meyer, M. T. Parker, R. Pollitzer, F. M. Prince, S. F. Quan, and P. Wagle. 1956. Recommended laboratory methods for the diagnosis of plague. Bull. World Health Organ. 14:457-509.

3. Burrows, T. W. 1963. Virulence of Pasteurella pestis and immunity to plague. Ergeb. Mikrobiol. Immunitätsforsch. Exptl. Therap. 37:59113.

4. Chen, T. H., A. Larson, and K. F. Meyer. 1964. Studies on immunization against plague. XVII. Experimental studies on the effectiveness of aluminum-hydroxide-adsorbed formalinkilled Pasteurella pestis. J. Immunol. 93:668676.

5. Chen, T. H., AND K. F. Meyer. 1954. Studies on immunization against plague. VII. A hemagglutination test with the protein fraction of Pasteurella pestis: a serologic comparison of virulent and avirulent strains with observations on the structure of the bacterial cells and its relationship to infection and immunity. $J$. Immunol. 72:282-298.

6. Chen, T. H., AND K. F. MeYER. 1966. An evaluation of Pasteurella pestis Fraction I-specific antibody for the confirmation of plague infections. Bull. World Health Organ. 34:911918.

7. Chen, T. H., S. F. Quan, aNd K. F. MeYer. 1952. Studies on immunization against plague.
II. The complement-fixation test. J. Immunol. 68:147-158.

8. Larson, C. L., C. B. Philip, W. C. Wicht, and L. E. Hughes. 1951. Precipitin reactions with soluble antigens from suspensions of Pasteurella pestis or from tissues of animals dead of plague. J. Immunol. 67:289-298.

9. Lawton, W. D., G. M. Fukui, and M. J. SurGALlA. 1960. Studies on the antigens of Pasteurella pestis and Pasteurella pseudotuberculosis. J. Immunol. 84:475-479.

10. Moody, M. D., AND C. C. WinTER. 1959. Rapid identification of Pasteurella pestis with fluorescent antibody. III. Staining Pasteurella pestis in tissue impression smears. J. Infect. Diseases 104:288-294.

11. OuChterlony, O. 1949. Antigen-antibody reactions in gels. Acta Pathol. Microbiol. Scand. 26:507-515.

12. OUCHTERLONY, O. 1953. Antigen-antibody reactions in gels. IV. Types of reactions in coordinated systems of diffusion. Acta Pathol. Microbiol. Scand. 32:231-240.

13. Petri, G. F. 1932. A specific precipitin reaction associated with the growth on agar plates of meningococcus, pneumococcus, and $B$. dysenteria (shiga). Brit. J. Exptl. Pathol. 13:380-394.

14. QuaN, S. F., W. KNAPP, M. I. GoldenberG, B. W. Hudson, W. D. Lawton, T. H. Chen, AND L. KARTMAN. 1965. Isolation of a strain of Pasteurella pseudotuberculosis from Alaska identified as Pasteurella pestis. An immunofluorescent false positive. Am. J. Trop. Med. Hyg. 14:424-432.

15. Sia, R. H. P., AND S. F. Chung. 1931-32. Use of antipneumococcus serum-agar for the identifcation of pneumococcal types. Proc. Soc. Exptl. Biol. 29:792-795.

16. Winter, C. C., W. B. Cherry, AND M. D. MoODY. 1960. An unusual strain of Pasteurella pestis isolated from a fatal human case of plague. Bull. World Health Organ. 23:408-409.

17. Winter, C. C., AND M. D. MoODY. 1959. Rapid identification of Pasteurella pestis with fluorescent antibody. II. Specific identification of Pasteurella pestis in dried smears. J. Infect. Diseases 104:281-287. 